\title{
HOW ARE BREWER'S SPARROWS AFFECTED BY THE ENCROACHMENT OF THE EXOTIC GRASS SPECIES, SMOOTH BROME (BROMUS INERMIS LEYSS.)?
}

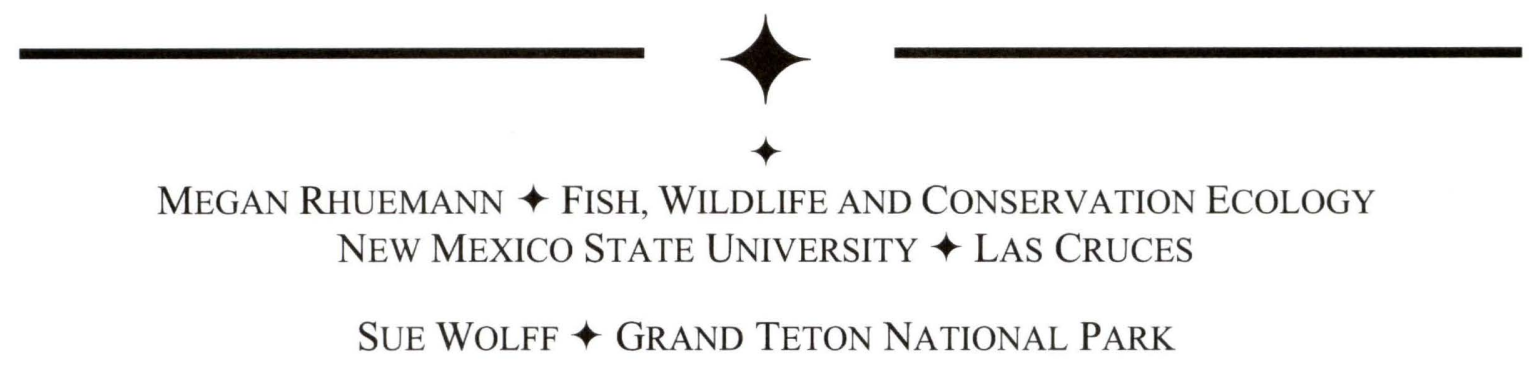

$\downarrow$ INTRODUCTION

Sagebrush habitats (Artemisia spp.) across the western United States have been continuously altered since the arrival of early European settlers. Habitat loss and fragmentation in sagebrush-dominated habitats has been attributed to domestic livestock, introduction of non-native vegetation, agricultural expansion, urbanization, and changes in ecological processes that regulate ecosystems (Knick et al. 2003). These alterations have resulted in landscape level changes; for example, it is estimated that between $50-60 \%$ of the nearly 63 million hectares once covered by sagebrush in the west have been either completely converted to non-native grasslands or now contain nonnative grasses in the understory (Miller and Eddleman 2001, West 2000 and1996). The encroachment of non-native plants that compete with native vegetation has been identified as one of the most serious threats to the health and integrity of sagebrush ecosystems throughout the west (Paige and Ritter 1999).

Grand Teton National Park is not immune to the decline of historic sagebrush habitat. For example, early settlers to Jackson Hole cultivated approximately 4,400 hectares of formerly sagebrush habitat known as the Kelly hayfields for hay with various perennial grasses (Daugherty 1999). One of these grasses, smooth brome (Bromus inermis Leyss.), is a native of Europe that reproduces by seed, rhizome, and tillers. This hardy perennial, introduced to North America from Europe and Asia, was highly successful in out-competing native vegetation and became the dominant grass species across the Kelly hayfields. Smooth brome has remained the dominant species at the Kelly hayfields despite the termination of farming in the early 1970's, and a mixture of sagebrush and smooth brome comprise the surrounding areas. In addition, over the last decade noxious weeds have spread into the Kelly hayfields and vicinity, competing with the native flora and further degrading the quality of sagebrush communities.

Grand Teton National Park is currently developing a plan to restore the Kelly hayfields to native vegetation. This project will have widespread effects on the native flora and fauna in the park. For example, several wildlife species will likely benefit from the restoration of this area including ungulates (e.g., bison, elk, pronghorn antelope and moose), breeding birds (e.g., greater sage-grouse, neotropical migratory birds), and numerous small mammals (e.g., jumping mice). In fact, the restoration of the Kelly hayfields is recommended in several alternatives for the management of the park except the no action alternative in the Bison and Elk Environmental Impact Statement (Morgenweck and Snyder 2005), a plan that aims to create and maintain natural foraging areas for elk and bison in the Jackson Hole area. Prior to the initiation of restoration efforts, park managers must determine benchmark goals for 
native habitat restoration.

This project used the avian community as a means of better understanding what comprises "suitable" habitat in the sagebrush ecosystem. We compared avian communities and Brewer's Sparrow reproductive success within the targeted restoration area with nearby undisturbed patches of sagebrush-dominated habitats. We determined threshold levels of smooth brome tolerated by sagebrush obligate bird species. We hope that this information will assist park biologists and managers in determining the extent of restoration needed for wildlife associated with sagebrush ecosystems. Furthermore, by using birds as indicators to measure the health of these park lands, we plan on using our findings when evaluating restoration plans.

Purpose: The purpose of this study was to determine the effects of non-native grass encroachment on sagebrush bird communities, as well as to compare bird use in sagebrush habitats experiencing varying levels of smooth brome invasion. Specific objectives include:

- To determine if sagebrush obligate bird species currently utilize sagebrush patches with a smooth brome understory.

- To compare nest success of Brewer's Sparrows in altered sagebrush habitat with nearby patches dominated by native species.

- To identify threshold levels of smooth brome encroachment beyond which Brewer's Sparrows will not occupy a site.

- To compare bird communities over varying degrees of habitat alteration.

\section{$\downarrow$ METHODS}

The study area was in the Kelly
hayfields and surrounding sagebrush
communities located at the southeast corner of
Grand Teton National Park (GRTE), Wyoming.
In unaltered habitats, the dominant shrub species
was mountain big sagebrush (Artemisia
tridentata spp. Vaseyana), occasionally
intermixed with antelope bitterbrush (Purshia
tridentata) or low sagebrush (Artemisia
arbuscula). Common native grass species
included Idaho fescue (Festuca idahoensis),
junegrass (Koeleria macrantha), and bluegrass
(Poa spp), while common forbs include sulphur buckwheat (Eriogonum umbellatum), yarrow (Achillea millefolium), arrowleaf balsamroot (Balsamorhiza sagittata), and lupine (Lupinus $s p p)$. The remnant hayfields consist primarily of smooth brome (Bromus inermis), but also contain other non-natives such as musk thistle (Carduus nutans) and Kentucky bluegrass (Poa pratensis).

Study sites included 1) altered patches within the Kelly hayfields that contain smooth brome with little to no sagebrush, 2) sagebrush habitats adjacent to the Kelly hayfields with smooth brome encroachment and 3) intact, native sagebrush vegetation communities. Transects were randomly located and selected using GIS. Each transect was approximately $2 \mathrm{~km}$ long and consisted of at least 15 points separated by $125 \mathrm{~m}$. A minimum of 5 transects were surveyed for each vegetation type.

Several components were measured to assess the effects of smooth brome encroachment on avian communities: species diversity and occupancy, Brewer's Sparrow density, vegetation structure and species composition at and around nest sites, and Brewer's Sparrow reproductive success. To determine bird occupancy and diversity, we followed protocols already described in the GRTE Landbird Monitoring Protocol (2005). In summary, birds were surveyed using point count techniques. Fifteen points were located 125 meters apart on each transect. Surveyors visited each transect 3 times per season. Every point along each transect was surveyed for birds, beginning 15 minutes after sunrise and ending no later than 10AM. All birds seen and/or heard were recorded and their distance from each point was measured using a rangefinder. Bird surveys began in mid-May and were completed by the end of June, the time when breeding birds were most actively singing and establishing territories. Vegetation components measured along each transect included structure, cover, species composition, as well as ground litter type and depth.

Nest success of Brewer's Sparrows was measured using standard sampling protocols for nest searching and monitoring (Martin and Geupel, 1993). Using parental cues and systematic searching, surveys for nests were conducted during the nesting period to locate all birds nesting within 100 meters of each transect. All nests located were re-visited every 3-5 days 
to determine nest occupancy, number of eggs, and if young fledged. Nest failure was documented and determined if it was due to predation or abandonment, when possible. For example, egg fragments were inspected to identify if the egg was scavenged upon or if chick hatched. If eggs remained intact but without parental presence for an extended period of time ( $>1$ hour), the nest was considered abandoned. Vegetation components surrounding each nest were also measured. These included cover, location of nests within shrub, vegetation species utilized for nesting, as well as distance to nearest differing vegetation patch. Nest success rates were calculated using the Mayfield method (Mayfield 1961, 1975).

\section{$\downarrow \quad$ RESULTS AND DISCUSSION}

A total of 84 Brewer's Sparrow nests were located and monitored. Of these, 30 were found in sage/smooth brome habitat and 54 were found in native sage habitat. Although nests seemed to be more densely packed in the native sagebrush habitat, this area had a higher rate of failure when compared to the sage/smooth brome habitat (see table 1). Simple proportional figures of failure/success have been calculated.

\begin{tabular}{|l|l|l|l|}
\hline & \% Fail & \% Success & \% Unknown \\
\hline Native Sage & 55 & 43 & 2 \\
\hline $\begin{array}{l}\text { Sage/smooth } \\
\text { brome }\end{array}$ & 41 & 58 & 0 \\
\hline
\end{tabular}

Table 1: Nest Fate by Habitat

\section{Sage/Smooth brome}

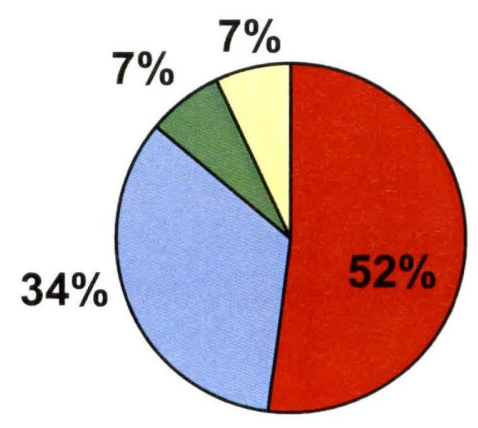

- predation

$\square$ weather

$\square$ abandonment

$\square$ dud

anknown
Nests that failed were examined to determine cause of failure. This information is broken down in order to show potential differences by habitat type (see figure 1). The most common cause of failure in both native sage and sage/smooth brome habitats was predation. The only predator observed in nests was the Wandering Garter Snake, although it is suspected that chipmunks and ground squirrels are also common predators. No Brown-headed Cowbird parasitism was observed.

A significant weather event occurred on June 14, 2006 and contributed to $34 \%$ of failures within the sage/smooth brome habitat type. This strong hailstorm impacted one study site, causing many of the incubating adults to abandon nests. However, it was noted that adults in this area began renesting attempts as early as 2 days after the weather event. Also of interest was the presence of dud eggs (eggs that never hatched) in the sage/smooth brome habitat type. This was never observed in the native sage habitat. Although dud eggs comprise a small portion of failure, this causes one to question if this could be attributed to difference in diet and/or overall health of adult Brewer's Sparrows between the two habitat types. 
are interesting trends between these two habitat types. The question of what exactly caused the difference in failure rates between habitat types opens many avenues for discussion and additional research. For example, this difference in failure rate could be attributed to predator abundance. Predators may simply be more abundant in the native sagebrush areas and not as well suited to the conditions that an understory of smooth brome creates. Additionally, nest concealment also likely plays a large role in nest fate. It often appears that nests in the sage/smooth brome habitat are well concealed due to the height and growing characteristics of smooth brome.

\section{$\downarrow$ Literature Cited}

Daugherty, J. 1999. A place called Jackson Hole: the historic resource study of Grand Teton National Park. Grand Teton National Park Service. Moose, WY.

Knick, S. T., D. S. Dobkin, J. T. Rotenberry, M. A. Schroeder, W. M. Vander Haegen, and C. Van Riper III. 2003. Teetering on the edge or too late? Conservation and research issues for avifauna of sagebrush habitats. The Condor 105:611-634.

Martin, T. E., and G. R. Geupel. 1993. Nest monitoring plots: methods for locating nests and monitoring success. Journal of Field Ornithology 64:507-19.

Mayfield, H. F. 1961. Nesting success calculated from exposure. Wilson Bulletin 73:255261.
Mayfield, H. F. 1975. Suggestions for calculating nest success. Wilson Bulletin 87:456-466.

Miller, R. F., and L. Eddleman. 2001. Spatial and temporal changes of Sage Grouse habitat in the sagebrush biome. Oregon State University Agricultural Experiment Station Technical Bulletin 151, Corvallis, Oregon.

Morgenweck, R., and M. Snyder. 2005. Draft Bison and Elk Management Plan and Environmental Impact Statement for the National Elk Refuge, Grand Teton National Park, and John D. Rockefeller, Jr., Memorial Parkway. July 21, 2005. www.fws.gov/bisonandelkplan/

Paige, C., and S. A. Ritter. 1999. Birds in sagebrush sea: Managing sagebrush habitats for bird communities. Partners in Flight Western Working Group, Boise, ID.

West, N. E. 1996. Strategies for maintenance and repair of biotic community Diversity on rangelands, p. 342-346. In R. C. Szaro and D. W. Johnston (EDS.), Biodiversity in managed landscapes: theory and practice. Oxford University Press, New York.

West, N. E. 2000. Synecology and disturbance regimes of sagebrush steppe ecosystems, p. 15-26. In P. G. Entwistle, A. M. DeBolt, J. H. Kaltenecker, and K. Steenhof (compilers), Proceedings: sagebrush steppe ecosystems symposium. USDI Bureau of Land Management Publication BLM/ID/PT-001001+1150, Boise, ID. 